\title{
PD- 4
}

\section{治療機器における最新技術}

東京医科大学泌尿器科

严木誠

外科領域における最新の治療機器の発達は目覚ましい。

各種レーザー・マイクロ波・ラジオ波・超音波・高周波などさまざまな物理 エネルギー、さらにはウォータージェット・コールドメスなどが目的に応じて 各種の手術処置に利用されている。そして一方では腹腔・後腹膜腔・胸腔・関 節腔など、いろいろの体腔において内視鏡手術が行われるようになり、それに 伴って各種の手術具も開発・改良されてきている。さらにロボット、マニピュ レーター、マイクロマシン、テレマイクロサージェリーなどはまさに日進月歩 である。とくに最近開発された片手 5 自由度の双腕マニピュレーターをマスタ ・スレーブ方式で操作可能としたシステムでは、ミリメートルオーダの精度で 縫合操作もできるようになったといわれており、この技術は将来の腔内手術の 主役となるであろう。

これら周辺機器の発達は、従来の手術という概念をまったく書き換えるよう に思える。そこで今回は、開発されつつある萌芽的最新治療技術と、すでに臨 床に取り入れられているが、将来多くの可能性を有する治療機器の新展開につ いて討論していただき、この領域に関する会員の認識を新たにしていただく予 走である。 